\title{
Urgensi Prinsip Proporsionalitas pada Perjanjian Mudarabah di Perbankan Syariah Indonesia
}

\author{
The Urgency of Proportionality Principle in Mudarabah Agreement on the \\ Indonesian Islamic Banking
}

\author{
Muhammad Sjaiful \\ Fakultas Hukum Universitas Halu Oleo Kendari \\ Jln. HEA Mokodompit, Kota Kendari, Sulawesi Tenggara, 93231, Indonesia. \\ Tel./Fax: +62-401-3194108 E-mail: saifulhamad@gmail.com
}

Submitted: Jul 24, 2015; Reviewed: Aug 8, 2015; Accepted: Aug 21, 2015

\begin{abstract}
The presence of Islamic banking institutions in Indonesia, is the need for the Muslims in Indonesia, to ensure their financial transactions based on sharia. One of practice sharia agreement that took place in Islamic banking in Indonesia, namely agreements financial transactions using the mudaraba. This paper aims to examine the application of the principle of proportionality to the mudaraba agreement practices in Islamic banking in Indonesia. This study can contribute as a scientific reference for the reconstruction of the mudaraba agreement to keep the principle of proportionality in accordance with Islamic principles. To achieve the intended purpose of the study, the research method used is a normative legal research methods, with a source of primary legal materials mudarabah written agreements contained in the Islamic banking in Indonesia. Also the secondary law in the form of literature and other scientific papers which contain legal doctrine and opinion of an expert on sharia agreement, particularly on the mudaraba agreement. The results showed that the application of the principle proporsioalitas in mudaraba agreement in Indonesian Islamic banking has not been going according to standards set by the sharia frame because in fact some of the clauses contained in mudarabah impressed provide opportunities for the shahibul maal (the Islamic banks) to disassociate ourselves from loss financial occur in the future, which is as if the financial loss was only covered by mudharib (businesses man), so that it deviates from the spirit of the principle of proportionality which should be the basis of the establishment of the nomenclature of the mudaraba agreement.
\end{abstract}

Keywords: Islamic Banking; Mudarabah Agreement; Proportionality Principle

Abstrak: Kehadiran lembaga perbankan syariah di Indonesia, adalah kebutuhan bagi bagi umat Islam di Indonesia, untuk menjamin transaksi keuangan mereka yang berbasis syariah. Salah satu praktik perjanjian syariah yang berlangsung di perbankan syariah di Indonesia, yaitu perjanjian transaksi keuangan yang menggunakan skema mudarabah. Tulisan ini bertujuan melakukan telaah penerapan prinsip proporsionalitas terhadap praktek perjanjian mudarabah di perbankan syariah di Indonesia. Penelitian ini dapat memberikan kontribusi sebagai rujukan ilmiah guna melakukan rekonstruksi perjanjian mudarabah agar tetap mengedepankan prinsip proporsionalitas menurut prinsip-prinsip syariah. Untuk mencapai tujuan penelitian yang 
dimaksud, metode penelitian yang digunakan adalah metode penelitian hukum normatif, dengan sumber bahan hukum primer yaitu beberapa perjanjian mudarabah tertulis yang terdapat pada perbankan syariah di Indonesia. Juga bahan hukum sekunder berupa literatur dan karya ilmiah lainnya yang berisi doktrin dan pendapat hukum ahli tentang perjanjian syariah, terutama tentang perjanjian mudarabah. Berdasarkan hasil analisa menunjukkan bahwa penerapan prinsip proporsioalitas dalam perjanjian mudarabah di perbankan syariah Indonesia belumlah berjalan sesuai standar yang ditetapkan menurut prinsip syariah sebab pada faktanya beberapa klausula yang tercantum dalam akad mudarabah terkesan memberi peluang begi pihak shahibul maal (pihak bank syariah) untuk berlepas diri dari kerugian finansial yang terjadi dikemudian hari, yang seolah-olah kerugian finansial itu hanya ditanggung oleh mudharib (pelaku usaha), sehingga ini menyimpang dari spirit prinsip proporsionalitas yang semestinya menjadi dasar tegaknya nomenklatur perjanjian mudarabah tersebut.

Kata Kunci: Perbankan Syariah; Perjanjian Mudarabah; Prinsip Proporsionalitas

\section{PENDAHULUAN}

Kehadiran perbankan syariah di Indonesia, di satu sisi memang patut disambut gembira karena ini merupakan salah satu sarana untuk mengakomodasikan keinginan umat Islam di Indonesia dalam rangka melakukan transaksi keuangan berbasis syariah. Kehadiran perbankan syariah tersebut, sekaligus merupakan titik pembaharuan bagi terlembagakannya secara formal penerapan perjanjian berbasis prinsip-prinsip syariah, sebagai salah satu manifestasi untuk memenuhi kebutuhan masyarakat muslim Indonesia dalam menjalankan aktivitas hubungan hukum bidang perjanjian dengan tetap merujuk prinsip-prinsip syariah.

Beberapa perbankan syariah di tanah air yang telah hadir mewarnai dinamika perbankan saat ini, antara lain yang dapat disebut, Bank Muamalat, BNI Syariah, Bank Syariah Mandiri, BRI Syariah, BCA Syariah, dan masih banyak lagi. Geliat ekonomi perbankan syariah yang semakin mengemuka dalam kegiatan ekonomi perbankan di tanah air, memang merupakan sebuah fakta yang tidak terbantahkan. Fakta lain juga menunjukkan berdasarkan data yang disampaikan oleh Kepala Eksekutif Lembaga Penjamin
Simpanan (LPS), Kartika Wirjoatmodjo pada tanggal 2 Desember 2014, bahwa peminat terhadap bank syariah di Indonesia sudah mencapai 17, 3 juta, dengan 2.990 kantor bank, dan 1.267 layanan syariah yang didukung oleh 43 ribu karyawan. Bahkan beberapa di antara perbankan syariah itu sudah ada yang merambah membuka cabang di beberapa provinsi di Indonesia. ${ }^{1}$

Sehubungan dengan itu, ada beberapa paket traksaksi keuangan berbasis syariah yang ditawarkan oleh beberapa bank syariah yang antara lain, perjanjian yang menyifatkan akad mudarabah, akad musyarakah, dan akad murabahah. Salah satu diantara paket produk syariah yang paling banyak diminati oleh nasabah bank syariah, yaitu perjanjian komersil berbasis akad mudarabah, atau yang dalam tulisan ini, disebut dengan perjanjian mudarabah.

Perjanjian mudarabah adalah sebuah bentuk perjanjian bernama yang berbasis prinsip-prinsip syariah yang dalam perjanjian tersebut terjadi hubungan hukum perikatan antara pemilik modal (shahibul maal)

\footnotetext{
1 Sumber: Lembaga Penjamin Simpanan. Dikutip pada laman website: http://goo.gl/bRoMWP (Diakses 16 Maret 2015).
} 
dengan yang akan menjalankan usaha (mudharib). Isi klausula perjanjian adalah pemilik modal (shahibul maal) berjanji menyerahkan sejumlah modal yang dimilikinya sesuai kesepakatan kepada pemilik usaha (mudharib). Berdasarkan kesepakatan, pihak pemilik usaha akan mengelola usahanya dengan menggunakan modal yang diperoleh dari pemilik modal. Hasil keuntungan yang diperoleh dari kegiatan usaha itu, akan dibagi dengan berdasarkan perjanjian bagi hasil antara pemilik modal dengan pelaku usaha.

Dalam praktik perjanjian mudarabah yang berlangsung di perbankan syariah di Indonesia, tampak bahwa bank syariah berkedudukan sebagai pemilik modal (shahibul maal), sedangkan nasabah sendiri yang bertindak sebagai pelaku usaha (mudharib). Di dalam skema perjanjian mudarabah, antara pemilik modal dengan pelaku usaha memiliki kedudukan yang seimbang, yaitu tidak pada tataran hubungan hukum antara satu dengan yang lainnya bersifat subordinat. Artinya, tidak boleh ada hubungan hukum dimana pihak satu menekan pihak lain dalam perjanjian.

Hubungan hukum yang seimbang antara pemilik modal dengan pelaku usaha dalam skema perjanjian mudarabah, maka tentu saja berimplikasi pada kerangka bangun hak dan kewajiban antara keduanya juga sama sifatnya. Sehingga skema perjanjian mudarabah semestinya dibangun berdasarkan prinsip proporsionalitas. Prinsip ini sebenarnya merupakan hasil temuan dalam teori hukum perjanjian yang diperkenalkan oleh Agus Yudha Hernoko, Guru Besar Fakultas Hukum Universitas Airlangga, dalam sebuah disertasi yang disusunnya untuk meraih de- rajat gelar doktor hukum.

Prinsip proporsionalitas, adalah sebuah prinsip yang menegaskan dalam hubungan hukum perjanjian komersil antara para pihak yang terbangun dengan berdasarkan proporsi masing-masing dengan bersandarkan kepada beban kerugian atau beban kerja yang akan diperoleh masing-masing pihak. Sehingga hubungan hukum mereka dalam kerangka bangun hak dan kewajiban itu, tidak selamanya bersifat matematis.

Dalam konteks penelitian ini, yang hendak ditelaah adalah seputar permasalahan penerapan prinsip proporsionalitas yang berlangsung pada fakta per-janjian mudarabah di beberapa bank sya-riah di Indonesia. Adapun yang perlu dititikberatkan di sini adalah apakah prinsip proporsionalitas tersebut, tetap berada da-lam frame syariah, yaitu proporsionalitas hak dan kewajiban para pihak dalam perjanjian mudarabah menurut standar yang dibenarkan oleh syariat Islam. Sebab penerapan prinsip proporsionalitas terhadap perjanjian mudarabah yang dipraktikkan beberapa perbankan syariah di di Indonesia, berdasarkan pra penelitian yang dilakukan peneliti, tampaknya masih bermasalah, sehingga perlu dilakukan rekonstruksi klausula perjanjian mudarabah itu sendiri, agar tetap terjaga konsistensinya menurut standar syariah.

Berpijak dari rumusan masalah penelitian itu, maka tujuan penelitian ini adalah hendak menganalisis secara mendalam beberapa klausula yang termuat dalam perjanjian mudarabah yang berlangsung di perbankan syariah Indonesia dengan mengaitkannya prinsip proporsionalitas menurut perspektif syariah. 


\section{METODE}

Tipe penelitian ini merupakan penelitian hukum normatif, yang karakteristik penelitiannya merupakan proses untuk menemukan aturan hukum, prinsip-prinsip hukum, maupun doktrin-doktrin hukum guna menjawab masalah pokok hukum yang dihadapi. ${ }^{2}$

Beranjak dari tipe penelitian ini yang sifatnya normatif, maka sumber bahan hukum yang digunakan sebagai rujukan analisis, mencakup sumber bahan hukum primer, yaitu beberapa perjanjian mudarabah tertulis yang terdapat pada perbankan syariah di Indonesia, seperti Bank Muamalat Cabang Kendari, BNI Syariah Cabang Kendari, BRI Syariah Cabang Kendari, dan Bank Syariah Mandiri Cabang Kendari. Juga bahan hukum sekunder berupa literatur dan karya ilmiah lainnya yang berisi doktrin dan pendapat hukum ahli tentang perjanjian syariah, terutama tentang perjanjian mudarabah.

Semua bahan hukum tersebut, dikumpulkan dengan menggunakan metode bola salju, kemudian diolah dengan melakukan inventarisasi terhadap semua bahan hukum yang relevan dan langkah selanjutnya adalah melakukan analisis terhadap semua bahan hukum dimaksud secara sistematis kualitatif dengan merujuk pada prinsip hukum proporsionalitas sebagai dasar berpijaknya.

\section{ANALISIS DAN PEMBAHASAN Perjanjian Mudarabah dalam Perspektif Hukum Islam}

Istilah mudarabah dalam beberapa literatur klasik Islam, biasa juga menggunakan istilah qiradh. Istilah qiradh digunakan oleh orang

2 Peter Mahmud Marzuki. (2005). Penelitian Hukum. Jakarta: Prenada Media Grup, hlm. 93.
Hijaz, sedangkan istilah mudarabah digunakan oleh orang Irak. Dengan demikian mudarabah dan qiradh adalah dua istilah untuk maksud yang sama. ${ }^{3}$

Mengenai pengertian mudarabah, ada beberapa ahli yang memberikan pendapatnya, antara lain Zarqa Mustafa Ahmad dalam Firdaweri ${ }^{4}$, bahwa mudarabah adalah pemilik harta (modal) menyerahkan modal kepada pengusaha untuk berdagang dengan modal tersebut, dan laba dibagi diantara keduanya berdasarkan persyaratan yang di sepakati. Arif Maftuhin ${ }^{5}$, juga memberikan pengertian mudarabah sebagai kontrak antara dua pihak dimana satu pihak yang disebut Rab al-mal (investor) mempercayakan uang kepada pihak kedua yang disebut mudharib (pengelola) untuk tujuan menjalankan usaha.

Abdullah Al-Mushlih dan Sholah AlShawi ${ }^{6}$, menjelaskan mudarabah sebagai penyerahan modal uang kepada orang yang berniaga sehingga dia mendapat prosentase keuntungan. Bentuk usaha ini melibatkan dua pihak, pihak yang memiliki modal namun tidak bisa berbisnis, dan pihak yang pandai berbisnis namun tidak memiliki modal, melalui usaha ini keduanya saling melengkapi. Apabila terjadi kerugian, maka kerugian itu sepenuhnya ditanggung oleh pemilik modal. Hal ini hendaknya dapat

Afzalur Rahman. (1996). Doktrin Ekonomi Islam Jilid 4. Yogyakarta: Dana Bakti Wakaf, hlm. 381382.

4 Firdaweri. (2014). "Perikatan Syariah Berbasis Mudarabah (Teori dan Praktik)". Jurnal Asas, 2 (7): 59.

5 Arif Maftuhin. (2004). Menyoal Bank Syariah Kritik Atas Interpertasi Bunga Bank. Jakarta: Paramadina, hlm. 77.

6 Abdullah al-Muslih dan Sholah Al-Shawi. (2004). Fiqih Ekonomi Keuangan Islam. Jakarta: Darul Haq, hlm. 171. 
dipahami bahwa yang rugi tidak hanya pemilik modal saja, tetapi juga pekerja atau pelaksana dengan rugi tenaga dan pikiran.

Sutan Remi Sjahdeini ${ }^{7}$, menjelaskan bahwa mudarabah adalah suatu transaksi pembiayaan berdasarkan syari'ah. Kepercayaan merupakan unsur terpenting dalam hal ini kepercayaan dari pemilik modal (investor) terhadap pelaksana usaha. Apabila usaha tersebut mengalami kegagalan, sehingga terjadi kerugian, yang sampai mengakibatkan sebagian atau seluruh modal yang ditanamkan oleh pemilik modal habis, maka yang menanggung kerugian keuangan hanya pemilik modal sendiri, sedangkan pelaksana usaha sama sekali tidak menanggung atau tidak harus mengganti kerugian atas modal yang hilang, kecuali apabila kerugian tersebut terjadi sebagai akibat kecurangan yang dilakukan oleh pelaksana usaha.

Pelaksana usaha hanya menanggung kehilangan atau resiko berupa waktu, fikiran, dan jerih payah yang telah dicurahkan selama mengelola usaha, serta kehilangan kesempatan untuk memperoleh sebahagian dari pembagian keuntungan yang berdasarkan perjanjian mudarabah itu diperjanjikan. Dalam transaksi mudarabah resiko finansial sepenuhnya dipikul oleh pemilik modal sedangkan pelaksana usaha sama sekali tidak memikul resiko finasial, yang dipikulnya hanyalah resiko nonfinansial.

Perseroan mudarabah (qirad) juga dapat didefinisikan sebagai perseroan yang dibentuk oleh pihak penyandang dana (sha-

Sutan Remi Sjahdeini. (2005). Perbankan Islam dan Kedudukannya dalam Tata Hukum Perbankan Indonesia. Jakarta: PT Pustaka Utama Grafiti, hlm. 28. hibul mal) dan pihak pengelola (mudarib), dengan kata lain perseroan mudarabah terbentuk dengan meleburnya harta dan badan. Keuntungan dari usaha perseroan mudarabah dibagi berdasarkan kesepakatan sedangkan kerugian usaha (kewajiban perseroan) ditanggung oleh shahibul maal. Sahnya atau terbentuknya perseroan mudarabah terjadi jika shahibul maal telah menyetorkan harta kepada mudarib. Pihak shahibul maal tidak diperbolehkan ikut bekerja mengelola perseroan bersama mudharib. Begitu pula pihak mudharib tidak diperbolehkan melakukan suatu kegiatan usaha atau transaksi tertentu tanpa seijin dari pihak shahibul maal ${ }^{8}$.

Dari pengertian mudarabah tersebut, dalam perspektif hukum Islam, yang menjadi dasar hukum bagi kebolehan aktivitas perjanjian mudarabah, adalah Hadits Nabi Muhammad, yang diriwayatkan dari Ibnu Abbas, bahwa saydina Abbas bin Abdul Muthalib jika memberikan dana kemitra usahanya secara mudarabah ia mensyaratkan agar dananya tidak dibawa mengarungi lautan, menuruni lembah yang berbahaya, atau membeli ternak, jika menyalahi peraturan tersebut yang bersangkutan bertanggung jawab atas dana tersebut. Disampaikanlah syarat-syarat tersebut kepada Rasulullah SAW, dan Rasulullah membolehkannya (HR Tabrani) $)^{9}$.

8 Taqiyuddin An Nabhani. (2000). "Membangun Sistem Ekonomi Alternatif: Perspektif Islam (an Nidlam al Iqtishadi fil Islam", alih bahasa Moh. Magfur Wachid, Cet. V. Surabaya: Risalah Gusti, hlm. 160-161.

9 Nasrodin. (2009). "Analisis Fiqih terhadap Implementasi Pembiayaan Modal Kerja IB pada PT Bank Tabungan Negara (Persero), TBK Kantor Cabang Syariah Jogjakarta. Jurnal Lariba, 2(12): 245. 
Dasar hukum mudarabah menurut hukum Islam, juga berdasarkan ijma sahabat Nabi Muhammad SAW, sebagai berikut:

Imam Malik meriwayatkan dalam al-Muwaththa' dan Syafi'i dalam al-Musnad, bahwa Abdullah dan Ubaidullah keduanya putra Umar r.a, pernah pergi ke Irak menjadi pasukan perang. Ketika kembali mereka berjumpa dengan Abu Musa AlAsy'ari, pada saat itu Abu Musa menjadi amir (gubernur) di Bashrah. Saat itu Abu Musa berkata: Andaikan aku mampu memberikan sesuatu yang lebih bermamfaat untuk kalian, tentu aku akan melakukannya. Selanjutnya Beliau berkata; disini ada harta dari Allah SWT yang hendak aku kirimkan kepada Amirul Mukminin (Khalifah Umar bin Khathab), maka sekarang aku pinjamkan kepada kalian, sehingga kalian dapat membeli barang dagangan dari Irak, kemudian kalian jual di Madinah dan kalian mendapatkan keuntungan, sementara modal pokoknya kalian serahkan kepada Amirul Mukminin. Akhirnya Umar mengambil modal pokoknya dan separoh dari keuntungannya. Sedangkan kedua putranya diberi dari separoh keuntungannya. ${ }^{10}$

Adapun mengenai unsur-unsur (rukun) yang harus terdapat untuk terciptanya perjanjian mudarabah, para ulama ahli hukum Islam berbeda tentang unsur rukun mudarabah. Ulama Hanafiyah berpendapat bahwa unsur rukun mudarabah adalah ijab dan qabul, yaitu lafazh yang menunjukkan ijab dan qabul dengan menggunakan katakata mudarabah, atau muqaradhah atau kata-kata yang searti dengannya. Sebahagian besar ulama ahli hukum Islam, berpendapat bahwa unsur rukun mudarabah ada tiga,

10 Muhammad Abdul Aziz al-Halawi. (1999). Fatwa dan Ijtihad Umar bin Khattab. Surabaya: Risalah Gusti, hlm. 386. yaitu dua orang yang melakukan akad (alaqidani) ${ }^{11}$, modal (ma'qud alai), dan shighat (ijab dan Qabul). Ulama Syafi'iyah lebih merinci lagi bahwa rukun mudarabah menjadi lima macam yaitu: modal, pekerjaan, laba, shigat, dan dua orang yang ber-akad. ${ }^{12}$

\section{Konsep tentang Prinsip Proporsionalitas}

Prinsip proporsionalitas bermakna sebagai prinsip yang melandasi atau mendasari pertukaran hak dan kewajiban para pihak sesuai proporsi atau bagiannya. Menurut Agus Yudha Hernoko ${ }^{13}$, mengandalkan pembahagian hak dan kewajiban yang diwujudkan dalam seluruh proses hubungan kontraktual, baik pada fase pra-kontraktual, pembentukan kontrak, maupun pelaksanaan kontrak. Prinsip proporsionalitas sangat berorientasi kepada konteks hubungan dan kepentingan para pihak (menjaga kelangsungan bisnis).

Lebih lanjut, Hernoko ${ }^{14}$ merinci fungsi prinsip proporsionalitas, baik dalam proses pembentukan maupun pelaksanaan kontrak komersial, mencakup:

1. Dalam tahap pra-kontrak, prinsip proporsionalitas membuka peluang negosiasi bagi para pihak untuk melakukan pertukaran hak dan kewajiban secara fair. Olehnya itu, adalah tidak proporsional dan harus ditolak proses negosiasi yang berlandaskan iktikad buruk.

11 M. Ali Hasan. (2003). Berbagai Macam Transaksi dalam Islam (Fiqih Muamalat). Jakarta: PT Raja Grafindo Persada, hlm. 101.

12 Gemala Dewi, dkk. (2013). Hukum Perikatan Islam di Indonesia. Jakarta: Kerjasama Kencana Prenada Media Grup dengan Badan Penerbit Fakultas Hukum Universitas Indonesia, hlm. 133.

13 Agus Yudha Hernoko. (2008). Hukum Perjanjian (Asas Proporsionalitas dalam Kontrak Komersial). Jakarta: Prenada Kencana Media Grup, hlm. 173.

14 Ibid. 
2. Dalam pembentukan kontrak, prinsip proporsionalitas menjamin kesetaraan hak serta kebebasan dalam menentukan/mengatur proporsi hak dan kewajiban para pihak agar berlangsung secara fair.

3. Dalam pelaksanaan kontrak, prinsip proporsionalitas menjamin terwujudnya distribusi pertukaran hak dan kewajiban menurut proporsi yang disepakati/dibebankan para pihak.

4. Dalam hal terjadi kegagalan dalam pelaksanaan kontrak maka harus dinilai secara proporsional apakah kegagalan tersebut bersifat fundamental sehingga mengganggu sebahagian besar kontrak atau sekedar hal-hal yang sederhana/ kesalahan kecil.

5. Bahkan dalam hal terjadi sengketa kontrak prinsip proporsionalitas menekankan bahwa proporsi beban pembuktian kepada para pihak harus dibagi menurut pertimbangan yang fair.

Berdasarkan fungsi prinsip proporsionalitas, maka urgensi prinsip proporsionalitas dalam kerangka bangun perjanjian antara para pihak adalah untuk memberikan pengakuan hak, peluang, dan kesempatan yang sama kepada para pihak untuk menentukan pertukaran yang adil bagi mereka. Kesamaan bukan berarti kesamaan hasil melainkan kepada posisi para pihak dalam perjanjian yang mengandalkan kesetaraan hak dan kedudukan ${ }^{15}$.

Prinsip proporsionalitas tidak hanya penting untuk menghasilkan kontrak

15 Pranoto dan Itok Dwi Kurniawan. (2013). "Urgensi Asas Proporsionalitas dalam Kontrak Kerja Konstruksi sebagai Antisipasi Terjadinya Sengketa”. Jurnal Private Law, 2(7): 92. yang berkeadilan dan saling menguntungkan (keadilan substansial), namun dengan prinsip proporsionalitas penting juga untuk menekankan adanya fairness (keadilan dalam prosedur), sehingga atas perannya tersebut seyogyanya prinsip proporsionalitas dapat selalu terlibat dalam setiap proses pembentukan kontrak.

\section{Urgensi Prinsip Proporsionalitas dalam} Perjanjian Mudarabah di Perbankan Syariah

Penegakan prinsip proporsionalitas dalam nomenklatur perjanjian mudarabah di perbankan syariah, sebenarnya merupakan hal yang sangat urgen, sebab melalui prinsip proporsionalitas ini, akan dapat terdeskripsi porsi hak dan kewajiban masing-masing pihak, yaitu antara pemilik modal (shahibul maal) dengan pelaku usaha (mudharib).

Kerangka substansi prinsip proporsionalitas, sebagaimana yang dijelaskan secara filosofis oleh Agus Yudha Hernoko, merupakan pertukaran hak dan kewajiban antara para pihak yang harus dilihat secara proporsional tidak dengan berdasarkan kepada hubungan matematis saja. Berpijak dari pemikiran yang dikembangkan oleh Agus Yudha Hernoko tersebut, dalam konteks perjanjian mudarabah haruslah dilihat perimbangan hak dan kewajiban antara pemilik modal dengan pelaku usaha secara proporsional menurut persepektif syariah (hukum Islam).

Artinya, timbangan proporsionalitas antara pemilik modal dengan pelaku usaha tidaklah mesti dilihat dalam perspektif keuntungan dan kerugian yang pada akhirnya mesti ditanggung secara penuh oleh satu 
pihak saja. Misalnya, tatkala dalam kegiatan usaha berbasis perjanjian mudarabah, terjadi kerugian modal maka tentu kerugian itu tidak harus ditanggung oleh pihak pelaku usaha, sebab kerugian modal hanya ditanggung oleh pihak pemodal. Dasar hukumnya adalah Hadits yang diriwayatkan oleh Ibnu Syaibah, sebagaimana ungkapan sahabat Nabi SAW yaitu Ali bin Abi Thalib berkata, "Kerugian itu berdasarkan harta (modal), sedangkan keuntungan berdasarkan kesepakatan para mitra". Demikian pula bila terjadi kerugian tenaga atau pikiran yang dicurahkan dalam kegiatan usaha itu, tentu saja kerugian ditanggung oleh badan pengelola usaha (mudharib).

Pada konteks pembahagian keuntungan dalam perjanjian mudarabah maka pembahagian keuntungan tersebut dilakukan setelah penghitungan laba dan rugi ${ }^{16}$. Kemudian modal disisihkan kembali kepada pemiliknya (shahibul maal). Pembahagian keuntungan, dalam perspektif syariah dilakukan berdasarkan berdasarkan kesepakatan dari kedua belah pihak yaitu dengan menghitung nilai nisbah atau persentasenya. Tidak dibenarkan untuk menghitung pembahagian keuntungan dari kedua belah pihak dengan berdasarkan nilai nominalnya.

Apabila nilai keuntungan dalam perjanjian mudarabah dihitung berdasarkan nilai nominalnya, maka sebagian besar ahli hukum Islam (fuqaha), seperti Ibnu Qudamah, menyatakan perjanjian mudarabah tersebut menjadi rusak (cacat). Sebab penentuan nilai nominal dalam perjanjian

16 Adiwarman A Karim. (2004). Bank Islam Analisis Fiqih dan Keuangan. Jakarta: Raja Grafindo Persada, hlm. 100. mudarabah dapat berimplikasi riba yang sangat dilarang dalam ajaran Islam. Misalnya, dalam perjanjian mudarabah ditetapkan apabila keuntungan diperoleh maka pihak shahibul maal mendapat porsi lima juta rupiah dan mudharib mendapatkan prosi tiga juta rupiah. Skema pembahagian keuntungan dengan cara demikian, tidak diperbolehkan dalam perspektif syariah. Yang diperbolehkan adalah pembahagian keuntungan berdasarkan persentase misalnya, shabul maal mendapat porsi sepuluh persen dan mudharib mendapat lima persen dari hasil keuntungan usaha kerjasama syirkah.

Apabila dalam perjanjian mudarabah tidak ada kesepakatan pembahagian hasil keuntungan (laba), maka pembahagian persentase keuntungan ditetapkan berdasarkan porsi andil dari masing-masing pihak yaitu tenaga yang dikeluarkan dan modal. Begitu juga dalam pelaksanaan perjanjian mudarabah tersebut mendatangkan kerugian, maka pembagian kerugian bukan didasarkan atas nisbah, tetapi berdasarkan porsi modal masing-masing pihak. Itulah sebabnya disebut sebagai nisbah keuntungan, bukan nisbah saja, karena nisbah bisa diterapkan bila bisnisnya untung.

Bila bisnisnya rugi kerugiannya itu harus dibagi berdasarkan porsi modal masing-masing pihak bukan berdasarkan nisbah, karena kerugian hanya ditanggung bagi para pemilik modal. Sebesar apapun keuntungan yang terjadi, kedua belah pihak selalu dapat menikmatinya, lain halnya kalau bisnisnya rugi. Kemampuan shahibul maal untuk menanggung kerugian finansial tidak sama dengan kemampuan mudharib, oleh sebab itu kerugian dibagi berdasarkan proporsi 
modal, dan karena proporsi modal atau finansial shahibul maal dalam kontrak ini adalah $100 \%$, maka kerugiannya ditanggung 100\% pula oleh shahib al-mal. Dilain pihak, karena proporsi modal mudharib dalam kontrak ini adalah $0 \%$, andaikata terjadi kerugian, mudharib akan menanggung kerugian (financial) $0 \%$ juga.

Sehubungan dengan penjelasan tersebut, urgensi peletakan prinsip proporsionalitas dalam perjanjian mudarabah adalah untuk mengkonkritkan proporsi hak dan kewajiban para pihak dalam kontrak yakni, antara pemilik modal (shahibul maal) dengan pelaku usaha (mudharib). Prinsip proporsionalitas tersebut, dapat mengonkritkan proporsi keuntungan dan kerugian yang didapatkan para pihak menurut timbangan syariah, bukan dengan berdasarkan proporsi hitungan matematis kerugian modal yang terjadi.

Sebagai ilustrasi, bila dalam pelaksanaan perjanjian mudarabah di kemudian hari terjadi kerugian yang dibarengi dengan berkurangnya atau musnahnya modal. Tentu saja, menurut prinsip dalam perjanjian mudarabah pemilik modal yang akan menanggung kerugian modal bukan pelaku usaha. Bila dikalkulasi secara matematis menurut hitungan modal, maka tampak seolah-olah yang mengalami kerugian dalam kerja sama mudarabah tersebut, adalah pemilik modal sedangkan pihak pelaku usaha, dibayangkan tidak mendapatkan kerugian apa-apa karena tidak harus ikut serta menanggung kerugian modal yang berkurang atau hilang.

Apabila kita menilik nomenklatur posisi para pihak dalam perjanjian mudarabah dengan menggunakan kaca mata prinsip proporsionalitas, maka sebetulnya kerugian tidak hanya dialami oleh pemilik modal tetapi kerugian juga dialami oleh pelaku usaha. Secara proporsional, kerugian finansial memang menjadi beban pemilik modal. Di lain pihak, kerugian juga tetap diderita oleh pelaku usaha. Letak kerugian yang dialami oleh pelaku usaha, yaitu dari segi curahan tenaga yang ia keluarkan serta banyaknya waktu yang ia korbankan. Memang betul, pihak pelaku usaha tidak dibebankan untuk menanggung kerugian modal. Namun dengan kerugian yang dialami dalam pelaksanaan perjanjian mudarabah, pelaku usaha tidak mendapatkan apa-apa dalam pekerjaannya. Apalagi kalau pekerjaan yang dia kerjakan itu hanya terkonsentrasi pada ikatan perjanjian mudarabah, maka bisa dipastikan si pelaku usaha mengalami dampak penderitaan psikis karena harus memenuhi nafkah kebutuhan sehari-hari, apalagi kalau kebutuhan itu juga terkait dengan kebutuhan keluarganya.

Jadi sebenarnya cukup adil dan sangat proporsional menurut timbangan hukum syariah bila kerugian modal bukan beban yang juga harus ditanggung oleh pelaku usaha. Sehingga, sangat tidak proporsional dan boleh dikatakan sangat tidak bijak apabila dalam persekutuan usaha mudarabah, kerugian modal juga harus ditanggung oleh pelaku usaha. Ibarat sudah jatuh tertimpa tangga pula, itulah barangkali peribahasa yang cocok digunakan kalau seandainya beban kerugian modal dalam pelaksanaan perjanjian mudarabah ditanggung oleh pelaku usaha.

Beban kerugian modal yang harus ditanggung oleh pemilik modal dalam pelaksanaan perjanjian mudarabah, secara filosofis, 
dapat dipandang sangat proporsional. Sebab, pemilik modal hanya mengalami kerugian dalam konteks sejumlah finasial yang dikeluarkannya. Pemilik modal, tidak mengalami kerugian tenaga dan curahan waktu yang dikeluarkannya.

Pemilik modal sesungguhnya adalah pihak yang berkeinginan mengembangkan modalnya dalam suatu kegiatan usaha tertentu yang dianggap memiliki prospek keuntungan ekonomi sangat menjanjkan. Akan tetapi, pemilik modal tidak memiliki keahlian sama sekali atau kecakapan (skill) yang dipersyaratkan untuk menjalankan kegiatan usaha tersebut. Atau mungkin juga, pemilik modal tidak memiliki waktu yang cukup untuk menjalankan kegiatan usaha dimaksud. Atas dasar itulah, pemilik modal lalu mengajak pelaku usaha yang dipandang cakap atau memiliki waktu yang cukup banyak untuk menjalankan kegiatan usaha tersebut, melalui mekanisme penyerahan modal yang diwujudkan dalam bentuk perjanjian mudarabah.

Dengan demikian, sangat proporsional bila kerugian modal hanya dibebankan kepada pemilik modal, sebab pemilik modal memang pada dasarnya tidak memiliki kecakapan tertentu ataukah harus mengorbankan banyak waktunya untuk menjalankan kegiatan usaha yang diperjanjikan dalam syirkah mudarabah. Artinya, pemilik modal dalam perjanjian mudarabah hanya bertumpu kepada kekuatan finasial yang dimilikinya.

Sebagai ilustrasi untuk memperkuat argumentasi tersebut, misalnya, di suatu daerah tertentu didirikan sekolah tinggi yang terbilang baru. Ternyata minat calon mahasiswa yang hendak kuliah di sekolah tinggi itu sangat besar. Seorang pemilik modal, melihat peluang usaha fotocopy dan penjilidan, sangat menjanjikan dan bisa mendapatkan keuntungan yang cukup besar. Pemilik modal tidak memiliki keahlian dan pengalaman untuk menjalankan kegiatan usaha tersebut. Pemilik modal lalu mengajak temannya yang kebetulan memiliki keahlian dan pengalaman usaha fotocopy dan penjilidan. Pada akhirnya, keduanya bersepakat untuk bekerja sama menjalankan kegiatan usaha fotocopy dan penjilidan. Bentuk kerja sama dituangkan melalui skema perjanjian mudarabah.

Mencermati ilustrasi perjanjian mudarabah tersebut, apabila di kemudian hari terjadi kerugian, dengan menggunakan pendekatan prinsip proporsionalitas, maka adalah wajar bila pemilik modal yang hanya menanggung kerugian finansial, sedangkan pelaku usaha fotocopy hanya menanggung kerugian tenaga, waktu, dan pemikiran yang sudah dicurahkannya.

Merupakan ketidakadilan dan tidak proporsional, bila pelaku usaha juga diharuskan turut menanggung kerugian modal apalagi sampai kepada keharusan untuk mengganti modal yang hilang atau berkurang. Begitu juga, sangat tidak proporsional apabila pemilik modal harus memberikan kompensasi finansial atau katakanlah sebagai uang pengganti kepada pelaku usaha yang telah mencurahkan tenaga, pikiran dan mengorbankan waktunya apabila terjadi kerugian. Sebab hubungan hukum, antara pemilik modal dengan pelaku usaha bukanlah hubungan hukum antara majikan dengan buruh, tetapi adalah hubungan hukum yang sifatnya kemitraan. 
Lain halnya apabila, pelaku usaha terbukti melakukan kelalaian dalam kegiatan usaha ataukah beritikkad buruk, maka dalam konteks demikian, pemilik modal dapat mengajukan gugatan kepada pengadilan, dengan menunjukkan bukti-bukti kuat kepada hakim, bahwa pelaku usaha memang benar lalai dalam kegiatan usaha yang dijalankan, ataukah pelaku usaha terbukti memang beritikkad buruk menyalahgunakan modal yang dipercayakan pemiliknya, untuk suatu kegiatan usaha mudarabah. Bila terbukti di muka hakim, maka tentu saja pelaku usaha berkewajiban mengganti modal tersebut kepada pemiliknya.

Kerja sama usaha mudarabah tidak hanya menafikan beban kerugian modal kepada pelaku usaha, tetapi juga tidak membolehkan pemilik modal untuk melakukan intervensi usaha, semuanya diserahkan kepada kreativitas dan strategi usaha menurut pendapat pelaku usaha. Akan tetapi, pelaku usaha juga tidak diperbolehkan untuk melakukan kegiatan usaha lainnya diluar kesepakatan tanpa izin dari pemilik modal.

Skema perjanjian mudarabah yang ditetapkan oleh hukum syariah tersebut merupakan mekanisme untuk menjaga proporsionalitas beban hak dan kewajiban antara shahibul maal dengan mudharib. Sebab dalam perjanjian mudarabah, penekanan hasil akhir dari perjanjian adalah nisbah atau pembahagian keuntungan, sehingga tentu saja proporsi pembahagian beban kerja antara kedua pihak, yang ditetapkan oleh hukum syariah, tidak lain adalah untuk menjaga kualitas dan keberlangsungan usaha, agar hasil akhir perjanjian yaitu nisbah dapat tercapai dan memuaskan kedua belah pihak.

\section{Studi Penerapan Prinsip Proporsionalitas} pada Perjanjian Mudarabah di Perbankan Syariah Indonesia

Berdasarkan hasil pengamatan penulis terhadap nomenklatur perjanjian mudarabah yang dipraktikkan pada beberapa perbankan syariah yang ada di Indonesia, tampaknya shahibul maal atau pemilik modal yang dalam hal ini adalah perbankan syariah itu sendiri, masih menempatkan jaminan sebagai persyaratan wajib yang harus dipenuhi oleh mudharib yaitu pelaku usaha itu sendiri. Menurut pendapat penulis, penempatan jaminan, dalam perjanjian mudarabah sebagai syarat mutlak memang tidak menjadi persoalan kalau, jaminan yang dimaksud adalah dipandang sebagai strategi untuk menjamin mudharib untuk tetap berhati-hati dalam menggunakan modal yang diberikan oleh shahibul maal (bank syariah).

Namun demikian, penempatan barang jaminan tersebut, sebenarnya menurut penulis dalam perspektif prinsip proporsionalitas, merupakan cacat hukum yang akan merusak nomenklatur perjanjian mudarabah. Sebab, dalam perjanjian mudarabah yang lebih ditekankan adalah hubungan hukum yang bersifat kemitraan atau hubungan kerja sama usaha bersama. Karakteristik hubungan kemitraan yang menonjol dalam perjanjian mudarabah tersebut, meniscayakan antara kedua belah pihak, yaitu shahibul maal dan mudharib tidak boleh diikat dengan adanya perjanjian tambahan sebagai sebuah persyaratan bagi tegaknya kerangka bangunan perjanjian mudarabah tersebut, seperti yang tampak pada fakta hukum perjanjian mudarabah yang dipraktekkan di beberapa perbankan syariah di Indonesia, yang telah me- 
nempatkan persyaratan adanya jaminan yang harus dipenuhi oleh mudharib, yang jaminan ini bisa dijadikan sebagai nilai pengganti dari nilai modal yang sudah digunakan oleh mudharib apabila dikemudian hari mudharib tidak mampu mengembalikan modal tersebut dengan alasan bahwa mudharib telah melakukan kelalaian atau wanprestasi.

Pada hakikatnya, persyaratan jaminan yang harus dipenuhi mudharib sebetulnya merupakan cacat hukum, yang secara proporsionalitas, merusak nomenklatur atau karakteristik perjanjian mudarabah itu sendiri. Sebab dengan penempatan jaminan, dapat berimplikasi merubah karakteristik perjanjian tersebut menjadi perjanjian utang piutang.

Argumentasinya bahwa hakekat keberadaan jaminan merupakan bentuk kerangka pemaksaan kepada mudharib untuk lebih menjaga modal shahibul maal. Artinya, perjanjian semakin menjebak kedua belah pihak untuk menjadikan modal sebagai objek perjanjian. Bila modal yang dijadikan sebagai objek utama perjanjian maka secara filosofis menjadikan perjanjian tersebut sebagai perjanjian utang piutang. Padahal sebenarnya dalam perjanjian mudarabah yang menjadi objek perjanjian bukanlah modal itu sendiri tetapi yang menjadi objek perjanjian adalah nisbah yaitu pembahagian hasil keuntungan yang diperoleh antara shahibul maal dengan mudharib.

Dalam konteks penempatan prinsip proporsionalitas, sebagaimana yang telah dibahas pada paragraph sebelumnya, maka proporsi hubungan antara shahibul maal dan mudharib adalah hubungan hubungan yang sama-sama menanggung kerugian dalam konteks kerugian yang berbeda. Kerugian modal akan diterima oleh shahibul maal dan kerugian tenaga, fikiran, dan waktu dialami oleh mudharib. Bila dikemudian hari, terdapat kecurigaan shahibul maal bahwa kerugian modal adalah akibat dari itikad buruk dan kelalaian dari mudharib maka mekanisme penyelesaian sengketanya adalah shahibul maal dapat mengajukan gugatan ke pengadilan dengan mengajukan sejumlah bukti-bukti kuat yang memungkinkan untuk itu.

Bila dalam hasil pemeriksaaan di pengadilan, mudharib betul-betul beritikad buruk atau lalai, maka hakim dapat memberikan keputusan hukum untuk memaksa mudharib mengembalikan modal yang digunakannya itu. Sehingga dalam konteks demikian, tergantung dari perintah hakim kepada mudharib apakah hakim memerintahkan untuk mengembalikan modal tersebut dalam jangka waktu yang ditentukan ataukah hakim dapat saja memerintahkan untuk mengeksekusi harta pribadi mudharib dalam rangka mengembalikan modal milik shahibul maal.

Berdasarkan hasil pelacakan penulis terhadap sejumlah klausula yang tertuang dalam perjanjian mudarabah seperti yang tampak pada perbankan syariah termasuk di Indonesia, tampak hubungan hukum yang tidak dibangun atas dasar azas proporsionalitas menurut perspektif syariah. Hubungan hukum yang tampak adalah hubungan hukum yang sifatnya sub-ordinat, yaitu posisi shahibul maal (bank syariah) yang tampak sebagai posisi yang mendominasi mudhar$i b$ (pelaku usaha). Sehingga yang tampak adalah hubungan hukum antara debitur dengan kreditur, suatu hubungan hukum yang 
secara proporsionalitas menurut perspektif syariah, telah melanggar hubungan hukum yang seharusnya bersifat kemitraan, sebagaimana hubungan hukum yang seharusnya menjadi kerangka dasar dalam perjanjian mudarabah itu sendiri.

Dominasi shahibul maal misalnya tampak dalam klausula perjanjian yang menetapkan kewajiban bagi mudharib untuk melakukan pembayaran nisbah secara periodik, yang apabila mudharib tidak mampu melakukannya maka maka mudharib diberikan kelonggaran dengan mengangsurnya berdasarkan persentase nisbah yang disepakati pada awal perjanjian dengan melihat pada dasar patokan modal menurut perkalian yang dihitung sendiri oleh pihak bank syariah.

Dengan demikian, tampak bahwa penerapan prinsip proporsionalitas menurut perspektif syariah pada praktek perjanjian mudarabah di Indonesia, belum berjalan sebagaimana menurut koridor syariah. Tampak pengabaian prinsip proporsionalitas dalam praktek perjanjian mudarabah tersebut. Yang tampak adalah hubungan hukum bersifat sub-ordinat yang melahirkan dominasi shahibul maal kepada mudharib. Kendatipun hubungan hukum tersebut, seolah-olah sebagai hubungan hukum mudarabah tetapi sebenarnya itu hanya kamuflase. Karena pada hakikatnya, hubungan hukum yang tampak adalah hubungan hukum utang piutang, yang memposisikan mudharib sebagai debitur dan shahibul maal sebagai kreditur.

\section{PENUTUP}

Perjanjian mudarabah adalah perjanjian komersil berbasis syariah dengan karateris- tik yang khas. Yaitu hubungan hukum antara shahibul maal dengan mudharib yang secara khas bersifat kemitraan yang tidak ada saling mendominasi satu sama lain. Masingmasing pihak, mendapatkan kerugian dan keuntungan berdasarkan proporsi masingmasing menurut perspektif syariah. Nisbah dibagi berdasarkan persentase menurut kesepakatan sedangkan kerugian ditanggung menurut porsi yang dimasukkan dalam perjanjian seperti, kerugian modal ditanggung shahibul maal sedangkan kerugian tenaga, waktu dan pikiran ditanggung mudharib.

Dalam praktik perjanjian mudarabah pada perbankan syariah di Indonesia, prinsip proporsionalitas menurut perspektif syariah belum berjalan sebagaimana mestinya. Sebaliknya, yang tampak justru hubungan hukum yang lebih didominasi oleh pihak shahibul maal maka menjadilah posisi hubungan hukum antara kreditur dan debitur sebagaimana yang tampak dalam karakter perjanjian utang piutang.

Untuk itu, rekomendasi penting yang sangat mendesak dilakukan adalah sangat diperlukan adanya regulasi baru spesifik mengatur hubungan hukum transaksi keuangan berbasis komersil yang benar-benar murni berjalan pada koridor syariah. Guna menghindari sebuah bentuk perjanjian komersil yang hanya berkedok dibalik topeng syariah tetapi sejatinya bukanlah syariah. Ini penting dilakukan agar umat Islam di Indonesia dapat menjalankan hubungan muamalahnya satu sama lain tetap pada niat mendapatkan ridho dari Allah SWT, bukan sebaliknya, menjerumuskan mereka dosa kepada Allah SWT. 


\section{BIBLIOGRAFI}

Abdullah Al-Muslih dan Sholah Al-Shawi. (2004). Fiqih Ekonomi Keuangan Islam. Jakarta: Darul Haq.

Adiwarman A Karim. (2004). Bank Islam Analisis Fiqih dan Keuangan. Jakarta: Raja Grafindo Persada.

Afzalur Rahman. (1996). Doktrin Ekonomi Islam Jilid 4. Yogyakarta: Dana Bakti Wakaf.

Agus Yudha Hernoko. (2008). Hukum Perjanjian (Asas Proporsionalitas dalam Kontrak Komersial). Jakarta: Prenada Kencana Media Grup.

Arif Maftuhin. (2004). Menyoal Bank Syariah Kritik Atas Interpertasi Bunga Bank. Jakarta: Paramadina.

Firdaweri. (2014). "Perikatan Syariah Berbasis Mudarabah (Teori dan Praktik)". Jurnal Asas, 2 (7): 59.

Gemala Dewi, dkk. (2013). Hukum Perikatan Islam di Indonesia. Jakarta: Kerjasama Kencana Prenada Media Grup dengan Badan Penerbit Fakultas Hukum Universitas Indonesia.

M. Ali Hasan. (2003). Berbagai Macam Transaksi dalam Islam (Fiqih Mua- malat). Jakarta: PT Raja Grafindo Persada.

Muhammad Abdul Aziz al-Halawi. (1999). Fatwa dan Ijtihad Umar bin Khattab. Surabaya: Risalah Gusti.

Nasrodin. (2009). “Analisis Fiqih terhadap Implementasi Pembiayaan Modal Kerja IB pada PT Bank Tabungan Negara (Persero), TBK Kantor Cabang Syariah Jogjakarta." Jurnal Lariba, 2(12): 245.

Pranoto dan Itok Dwi Kurniawan. (2013). "Urgensi Asas Proporsionalitas dalam Kontrak Kerja Konstruksi sebagai Antisipasi Terjadinya Sengketa". Jurnal Private Law, 2(7): 92.

Peter Mahmud Marzuki. (2005). Penelitian Hukum. Jakarta: Prenada Media Grup.

Sutan Remi Sjahdeini. (2005). Perbankan Islam dan Kedudukannya dalam Tata Hukum Perbankan Indonesia. Jakarta: PT Pustaka Utama Grafiti.

Taqiyuddin An Nabhani. (2000). Membangun Sistem Ekonomi Alternatif: Perspektif Islam (an Nidlam al Iqtishadi fil Islam". Alih bahasa: Moh. Magfur Wachid, Cetakan kelima. Surabaya: Risalah Gusti. 